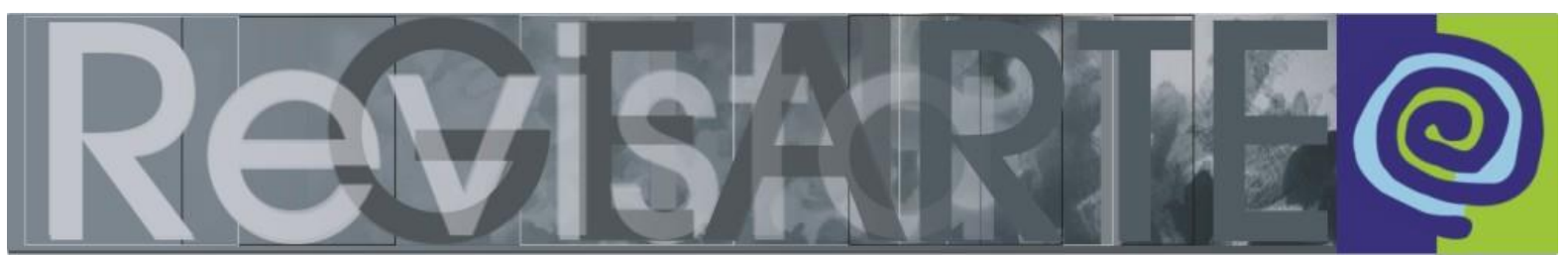

ISSN 2357-9854 | e-ISSN 2596-3198 (online)

\title{
Artesania como processo: o estágio curricular em Artes Visuais como espaço de observação e reflexão
}

\author{
Ana Paula Aparecida Caixeta \\ (Universidade de Brasília — UnB, Brasília/DF, Brasil) \\ Luiz Carlos Pinheiro Ferreira \\ (Universidade de Brasília — UnB, Brasília/DF, Brasil)
}

\begin{abstract}
RESUMO - Artesania como processo: o estágio curricular em Artes Visuais como espaço de observação e reflexão - $O$ texto apresenta diálogos a respeito do estágio curricular no âmbito da observação e da regência em Artes Visuais, abordando questões que transitaram pelo cotidiano formativo em licenciatura, pensando em quais reverberações foram proporcionadas à formação discente. A intenção é construir reflexões que atravessaram o estágio e promoveram interfaces com a artesania, considerando apontamentos sobre experiências no contexto da docência. $O$ aporte dialógico do texto reside na provocação de perspectivas vinculadas com um olhar atento acerca dos caminhos críticos que comportam discussões de um conhecimento sensível, que pensa a artesania como processo.
\end{abstract}

PALAVRAS-CHAVE

Artesania. Estágio curricular. Artes Visuais. Formação. Cotidiano.

RESUMEN - La artesanía como proceso: la pasantía curricular en Artes Visuales como espacio de observación y reflexión - El texto presenta diálogos sobre la pasantía curricular en el ámbito de la observación y la conducción en Artes Visuales, abordando temas que transitaron por la formación diaria en los cursos de pregrado, pensando en qué reverberaciones se aportaron a la formación del alumno. La intención es construir reflexiones que cruzaron la pasantía y promovieron interfaces con la artesanía, considerando apuntes sobre experiencias en el contexto de la docencia. El aporte dialógico del texto reside en la provocación de perspectivas ligadas a una mirada atenta a los caminos críticos que implican discusiones de un conocimiento sensible, que considera la artesanía como un proceso.

PALABRAS CLAVE

Artesanía. Pasantía curricular. Artes visuales. Formación. Diario.

ABSTRACT - Craftsmanship as process: the curricular internship in Visual Arts as space of observation and reflection - The text presents dialogues regarding the curricular internship under observation and the regency in Visual Arts, addressing issues that passed through the daily training in graduation, thinking about what reverberations were provided to the student formation. The intention is to build reflections that crossed the internship and promoted interfaces with craftsmanship, whereas notes on experiences in the context of teaching. The dialogical contribution of the text resides in the provocation of prospects linked with a watchful eye on the critical paths that involve discussions of a sensitive knowledge, which considers craftsmanship as process.

KEYWORDS

Craftsmanship. Curricular internship. Visual Arts. Formation. Everyday. 


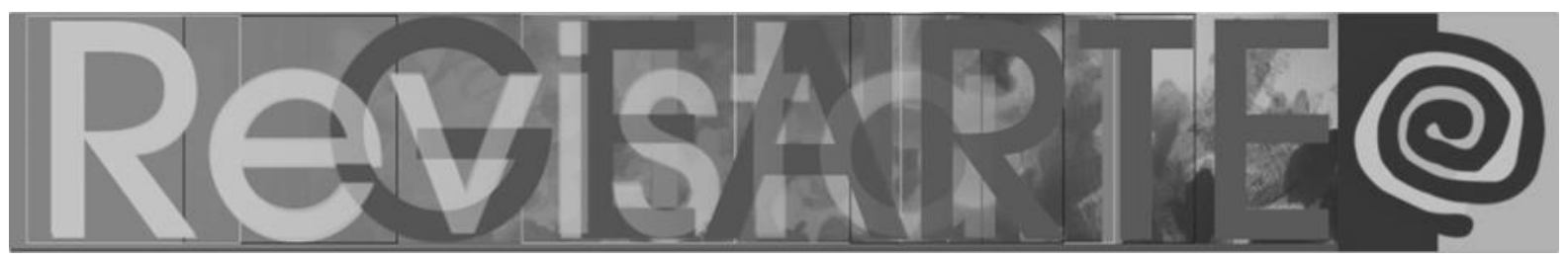

\section{Apresentação}

O artigo visa promover um debate a respeito de questões que transitaram pelo contexto de formação em Licenciatura no âmbito das Artes Visuais, a partir de reflexões sobre a experiência com o estágio curricular. Nosso intuito reside em pensar quais as reverberações e sentidos que o estágio curricular suscita enquanto possível construção de interfaces com a artesania. Intencionamos, nesse sentido, compreender como a artesania permeou determinadas atividades propostas em sala de aula, ocupando um lugar de formação sensível, histórico e cultural, bem como aquelas que estiveram presentes nas observações e nas práticas do ambiente escolar, em especial, nas aulas de Artes Visuais. $\mathrm{O}$ acesso a tais experiências formativas relacionadas com o conceito de artesania surgiu a partir dos diálogos teóricos/metodológicos estabelecidos em sala de aula, assim como pela experiência dos discentes com a prática pedagógica realizada nas escolas. Observamos tais questões no relatório crítico e reflexivo apresentado pelos discentes ao final do estágio. Ali encontramos apontamentos concernentes com a vivência em sala de aula realizada no momento de observação e com a prática pedagógica nas escolas no momento de regência.

Nesse aspecto, ao promovermos a escrita de um texto em conjunto, em sua dimensão dialógica, exercitamos reflexões que fizeram parte de nossa experiência docente ao ministrarmos a referida disciplina ${ }^{1}$. Essa iniciativa, que contempla diálogo, escrita, reflexão e um olhar atento para o cotidiano da sala de aula, surge por intermédio da provocação do tema proposto pelo dossiê. Tema que remete a interlocuções e, também, aos interesses de nossa pesquisa, contemplando elementos de um cotidiano particular de cada um dos professores pesquisadores, pensado aqui como espaço de reflexão e conhecimento provenientes do lugar da artesania - especialmente da artesania enquanto processo formativo.

Ao provocarmos consonâncias entre as experiências pedagógicas acerca das disciplinas de Estágio Supervisionado em Artes Visuais, considerando as 


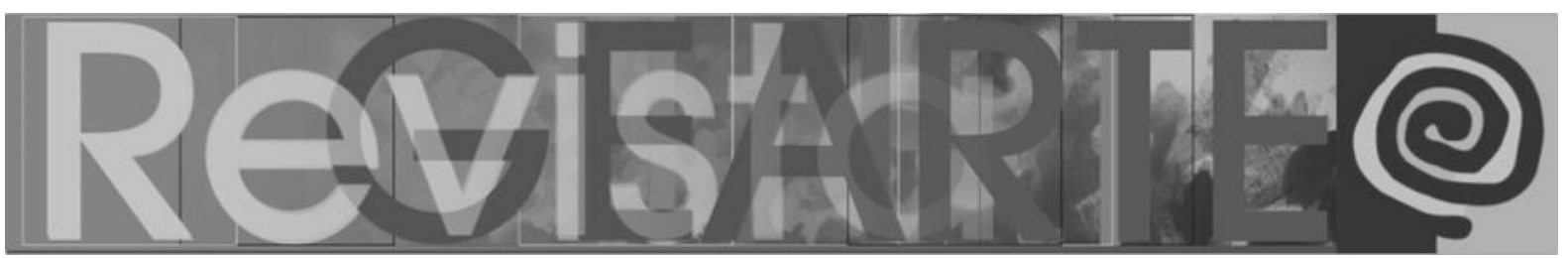

especificidades de cada uma, entendemos igualmente que ambas transitaram na esfera de uma formação particular, inerente aos discentes. Por isso, torna-se relevante pensar o lugar do estágio curricular no contexto formativo em Artes Visuais, sobretudo, quando as experiências pontuam aspectos narrativos entre aquilo que o discente aprende na instituição de ensino e sua trajetória formativa advinda de outra realidade. Pautados nessa perspectiva, entendemos o estágio curricular em Artes Visuais como "um currículo que enfatiza a cultura [...] e incorpora a reflexão pública e privada sobre o que fazemos, por que fazemos e quem nós somos" (DOLL JR., 1997, p. 142). Para William Doll Jr. (1997), o currículo deveria estar centrado na perspectiva do currere, ou seja, o modo verbal que enfatiza a ideia de curso a ser seguido, como um caminho orientado pela autorreflexão e a imaginação. Nesse aspecto, ao destacarmos o estágio curricular, buscamos a fonte do conceito utilizado por Doll Jr. (1997), ao apontar a perspectiva do currere. Compreendemos que ele parte daquilo que William E. Pinar (2007) assinala, que, para sustentar o estudo sistemático da autorreflexão dentro do processo educativo, inventa o método currere, associando-o com a "[...] forma latina do infinito de currículo [e] significa percorrer o caminho, ou, no gerúndio, percorrendo o caminho [...]" (PINAR, 2007, p. 65). Pinar fornece táticas para os alunos do currículo estudarem as analogias entre conhecimento acadêmico e histórias de vida, no interesse da autocompreensão e reconstrução social. Esclarecemos que não temos por intenção aprofundar a teoria do currículo a partir das proposições de Pinar (2007), no entanto, a perspectiva do currere nos interessa no que diz respeito ao estágio curricular, porque permite pensar as interfaces com a artesania a partir de um caminho percorrido pelo discente, no qual foi possível estabelecer comparações e reflexões que tangenciam tanto o contexto formativo institucional como outras experiências artísticas e culturais que fizeram parte de um repertório da artesania. Esta perspectiva associada ao processo de percorrer um caminho, iniciado desde o ingresso no Curso de Licenciatura em Artes Visuais, ponderando também questões atreladas com a trajetória pessoal dos discentes, leva-nos a considerar quais foram as experiências desses sujeitos 


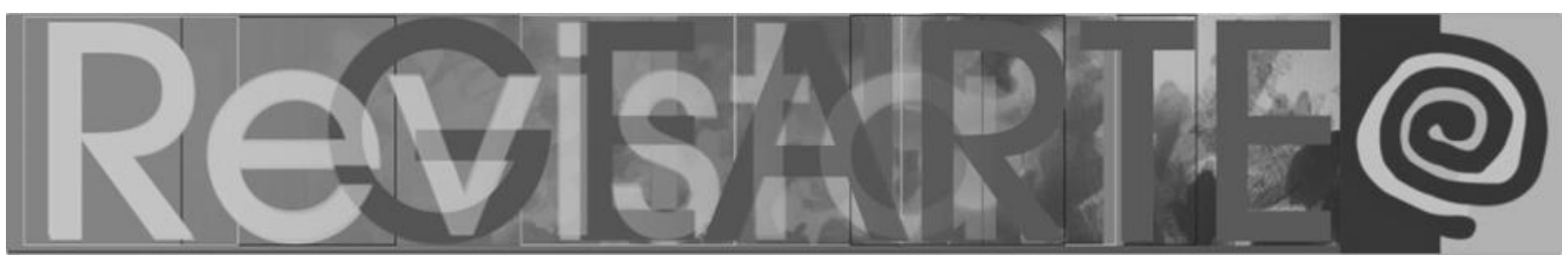

ao longo desse caminho. E, ainda: quais foram os objetos, imagens e referências visuais determinantes na sua formação cultural? De que modo os discentes lidam com as referências artísticas que são colocadas pela mídia? Qual o seu entendimento da artesania como expressão artística? Tais questões, embora não resolvidas neste breve estudo, serviram como mote para pensar o texto e suscitar outras indagações acerca de um momento extremamente decisivo na formação acadêmica dos discentes: o estágio curricular.

O que compõe esse cenário observado como fecundo lugar de aprendizagem nasce também de uma sensibilidade atenta ao cotidiano e as vivências, uma vez que é no momento de experiência com uma situação ou objeto, que possibilidades sensíveis transformam-se em mote para pensar a respeito daquilo que emana do humano, tornando-se elemento de aprendizagem. Uma vez que as diretrizes curriculares abrem seus horizontes para fenômenos estéticos compartilhados a partir de uma pluralidade semântica, é possível tornar o espaço de discussão a respeito da formação em Artes Visuais como um processo natural que comporta culturas e saberes múltiplos.

Por isso, quando mencionamos trajetórias formativas estamos nos referindo tanto ao nosso processo de formação/escolarização quanto aquele vivido por nossos discentes, especialmente no campo da experiência com o ensino de arte. Essa experiência do discente transita por outras esferas de conhecimento, alimentando-se não somente com aquele conhecimento apreendido na formação acadêmica, ou seja, um conhecimento institucionalizado e erudito. Acreditamos que o conhecimento pode ser potencializado por outras interfaces, inclusive, com a artesania, abrindo espaço para o inusitado em sala de aula, para os desafios da incerteza e, além disso, "[...] assegurando uma tomada de posição que privilegie a possibilidade de construção de conhecimento a partir de ideias, vivências e experiências que ganham sentido no/do cotidiano" (FERREIRA, 2015, p. 243). Além disso, quem ganha com isso somos nós professores: discentes e participantes que atuam na construção de processos de conhecimento associados

CAIXETA, Ana Paula Aparecida; FERREIRA, Luiz Carlos Pinheiro. Artesania como processo: o estágio curricular em 488 Artes Visuais como espaço de observação e reflexão.

Revista GEARTE, Porto Alegre, v. 7, n. 3, p. 485-509, set./dez. 2020.

Disponível em: http://seer.ufrgs.br/gearte 


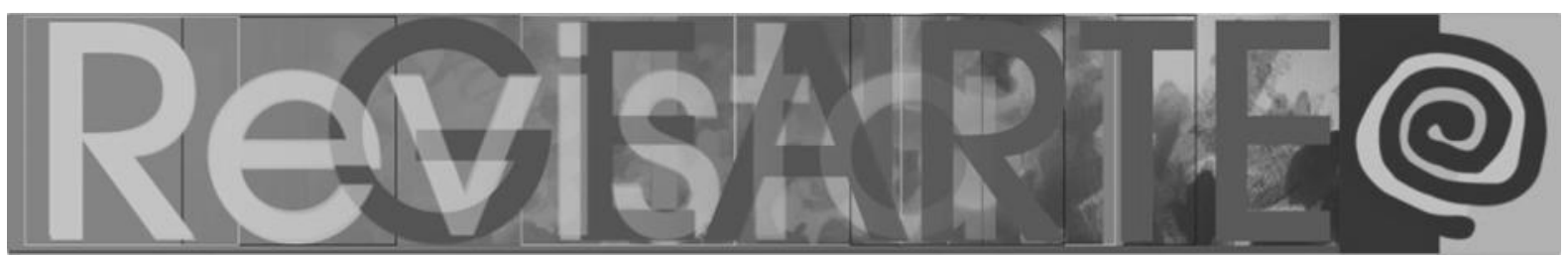

à cultura. Processos que estão imbricados aos modos de contar a sua própria experiência com o ensino de arte a partir daquilo que, em muitos casos, os discentes omitem ou desacreditam por considerarem não pertencer ao contexto da Arte.

Ainda a respeito do currículo, por uma consonância entre Pinar (2007) e as expectativas da $\mathrm{BNCC}^{2}$ no componente Arte, observa-se um esforço na tentativa de se construir um lugar para o conhecimento em linguagens que abarque as complexidades de um novo tempo. Especialmente quando se considera os novos meios comunicacionais e seus desdobramentos imagéticos, linguísticos, semânticos e culturais. Embora a adoção de um currículo em larga escala nem sempre contemple as especificidades oriundas dos efeitos da forma da arte e suas nuanças históricas e culturais, a interação incitada no componente em questão não poderá se fechar aos restritos comprometimentos estruturados por um único viés de abordagem. Deve-se, portanto, fomentar, por meio das indicações curriculares, um ambiente em que se pense o processo de fazer, de compreender e de refletir a respeito daquilo que é proveniente de manifestações sensíveis, inclusive, quando estas estão associadas a ideia de artesania como processo. $E$ isso se promove a partir de um docente disposto e atento aos movimentos provocados pela Arte.

Pautados por esse caminho, promovemos a escrita de um texto dialógico (BAKHTIN, 2004), permeado de reflexões que abarcaram a experiência com o estágio curricular e a artesania, considerando nesse contexto reflexões teóricas discutidas em sala de aula e apontamentos críticos sobre experiências. Destacamos que o interesse dialógico do texto reside na provocação de aspectos vinculados com um olhar atento acerca das discrepâncias entre aquilo que entendemos como artesania e o contexto de uma formação, por vezes, vinculada a referências eurocêntricas do ensino de arte. 


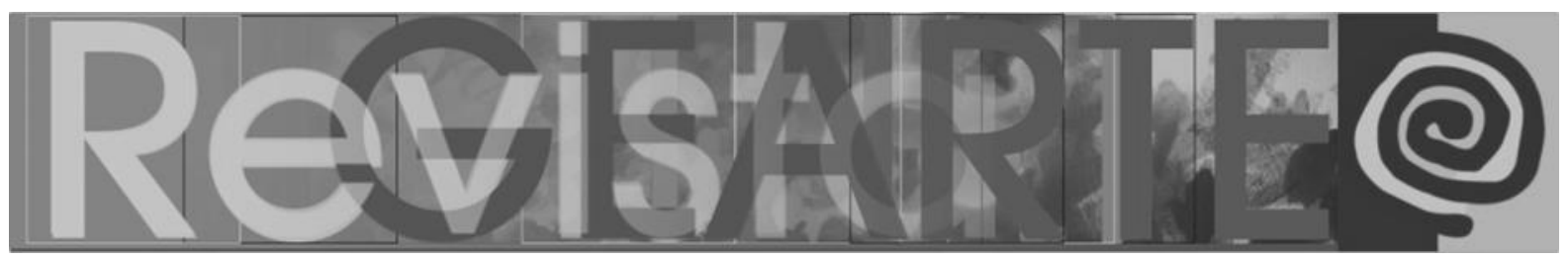

\section{O estágio curricular e a artesania: possíveis confluências}

O âmbito da formação representa um panorama significativo para o sujeito que busca o conhecimento, seja em contextos formativos ligados às instituições de ensino como respaldo para o ingresso na carreira docente, seja na perspectiva de uma formação pessoal, interligando interesses particulares associados com o campo das Artes Visuais. Apontamos tal questão para pensar, especificamente, a disciplina de $\mathrm{ESAV}^{3}$, justamente pela dimensão que ela tem para o contexto curricular. Sua dimensão abarca o momento em que o discente se depara com o advento da oportunidade de observar um lugar pelo qual transitou por longo período da sua formação institucional, visto agora sob outra perspectiva. Nesse sentido, observa-se como o discente, ao ter vivenciado a escola como aluno, reconhece aquele ambiente como familiar e, enquanto tema trazido para discussão no âmbito da licenciatura, resgata essa experiência como proveniente do particular em uma vivência agora mútua: como discente e como docente. No momento do ESAV, o sujeito adentra em um novo território institucional, pois o seu compromisso não está mais atrelado à condição de aluno da educação básica. Agora, sua posição é de futuro docente naquela área escolhida como um caminho de formação.

O estágio é campo de conhecimento (PIMENTA; LIMA, 2012). Assumido como experiência formativa, mas também como espaço de desafio no que diz respeito à atuação profissional do professor, o estágio curricular acaba por promover uma construção identitária importante do sujeito que o vivencia. Seja pela oportunidade de lidar com o reconhecimento do ensino como democrático e plural, seja pelo desafio de se compreender que o conteúdo não se encerra naquilo que a graduação promoveu. Dessa forma, a docência passa a ser vista pelo discente como configuração de um campo profissional preocupado com elementos teóricos e práticos que ultrapassam as paredes de uma sala de aula. Mais do que isso e ainda em concordância com Pimenta e Lima (2012), o estágio permite uma ressignificação no que diz respeito à construção de uma identidade docente, uma 


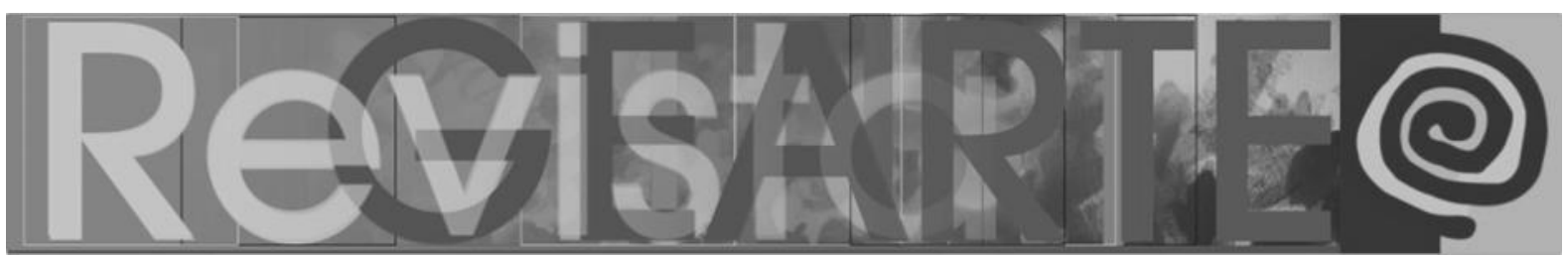

vez que os saberes científicos, pedagógicos e sensíveis requererão do estagiário um olhar mediador entre reflexão e crítica, mas também entre novos modos de pensar, sentir, agir e produzir.

Os caminhos da licenciatura, ainda fragmentados por um conjunto de disciplinas obrigatórias e eletivas, acaba por permitir uma construção fragmentada de uma identidade docente em formação. Quando, na oportunidade do estágio, propõe-se uma construção de conhecimento a partir das intersecções entre os saberes vivenciados no período da licenciatura e às observações e práticas em sala de educação básica, abre-se espaço para assumir um outro lugar de conhecimento: a prática de observação e regência.

Pimenta e Lima (2012), ao construírem uma reflexão a respeito do estágio e da docência, reforçam esse espaço de conhecimento, considerando o aprender da profissão como elegível de movimento e mudanças contínuas, cujas particularidades precisam ser destacadas e a reinvenção se torna uma ação necessária da profissão. As autoras ainda revelam uma preocupação com a observação como imitação ingênua, provocando o engessamento de um modelo, uma vez que se observa a ação do outro para aprender a agir. Entretanto, seria neste movimento de distanciamento por meio da observação em prol de uma aprendizagem que se despertaria no futuro docente a capacidade de compreender que a prática pela prática é vazia de reflexão, mas a prática vinculada a uma teoria e pensada dentro de especificidades formativas possibilita a construção de instrumentos para se pensar o ensino.

Uma vez superada a separação entre teoria e prática e construída a conexão da docência com a da reflexão contínua, assume-se a experiência promovida pelo estágio curricular como objeto de uma práxis (PIMENTA; LIMA, 2012). Nesse sentido, chama-nos a atenção o fato de que essa experiência é a primeira aproximação com uma realidade a ser vivenciada, vista pela perspectiva investigativa, reflexiva e formativa de um profissional pensante a respeito de sua 


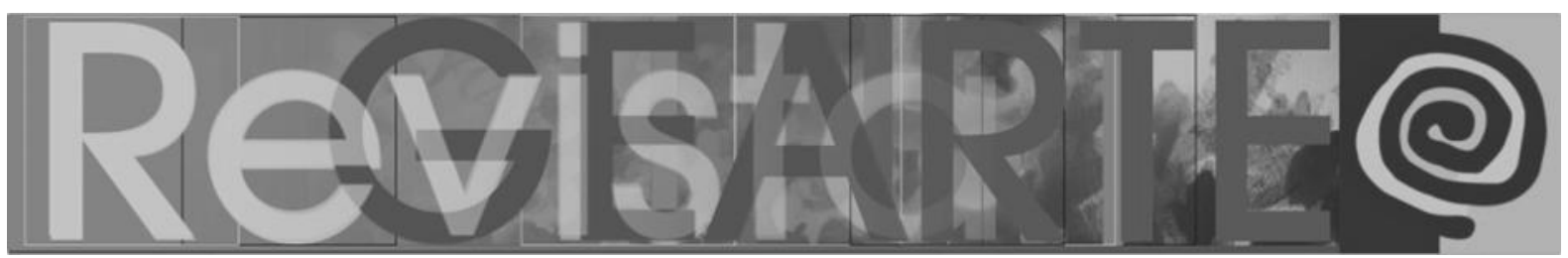

função social. No âmbito do ensino em Artes Visuais, compreender o currículo e pensar seus processos e sua aplicação implica também questionar aquilo que é proposto como um conhecimento dado e a validação designada a este conhecimento. Tourinho (2014) nos chama atenção para interesses que sejam articulados junto ao conteúdo, de modo que questionamentos e problematizações possam surgir a fim de se construir concepções que não estejam preocupadas com assertivas, mas com o caráter subjetivo dali proveniente.

Pode-se entender, portanto, que quaisquer intenções nascidas da experiência de estágio precisam estar abertas ao lugar das indagações como fator preponderante para construção de conhecimento em Artes Visuais. Observamos que as experiências vivenciadas pelos discentes com a artesania, despertaram sentidos críticos no contexto tanto da observação como da regência no momento do estágio curricular. Despertaram, inclusive, indagações sobre a prática docente, pois "a educação em artes visuais visa provocar deslocamentos, trazer à tona conflitos de nossas vivências, questionar nossas práticas e maneiras de olhar reforçando a experiência social que nos constrói enquanto seres culturais" (TOURINHO, 2009a, p. 3353). Vale ressaltar que um olhar que se proponha contextual, histórico e flexível às nuanças provenientes da dinâmica de sala de aula é um olhar genuinamente investigativo, capaz de confrontar saberes enrijecidos e fechados às particularidades estéticas de uma comunidade, de uma cultura.

Quando Richter (2003) abre espaço para discutir questões cotidianas no contexto de ensino em Artes Visuais, bem como aquilo que é proveniente de interculturalidades, ela nos atenta para as preocupações estéticas emergidas desses espaços múltiplos, banais, porém, enriquecidos de potencialidades discursivas. A autora vai chamar de "microestética" a produção sensível oriunda de individualidades e suas conexões afetivas, estabelecendo "[...] relação entre valores da ciência e valores estéticos" (RICHTER, 2003, p. 23). É nesse ínterim que reside a preocupação com aquilo que é observado e como pode ser absolvido 


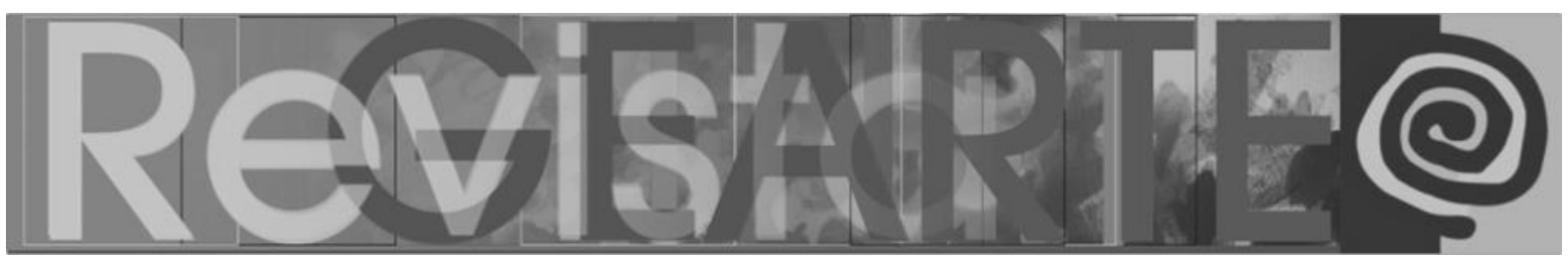

para se tornar reflexão. A artesania, nesse caso, torna-se mais que qualquer indicação temática ou curricular, um elemento conceitual capaz de transportar experiências de conhecimento. É o caso, por exemplo, das articulações textuais e imagéticas produzidas pelo discente ao vivenciar o estágio na escola.

Ao colher informações estruturais, pedagógicas, curriculares, mas também a respeito da comunidade escolar e suas particularidades, o sujeito é conduzido, em uma atitude artesanal, a tecer elementos capazes de promover reflexões e problematizações. Uma vez construído esse tecido composto por uma série de descrições a respeito do funcionamento da escola, ao discente será possível reconhecer o espaço para, então, se reconhecer ali - agora, numa instância de observação e, posteriormente, de prática. Espera-se, nessa elaboração, que o estagiário desenvolva competências reflexivas no que tangem questões conteudistas (imagem, conceito, forma, contexto, cultura etc.), observadas por um potencial agora crítico. Essa experiência o norteará a uma outra forma de percepção a respeito do ensino da arte, a medida em que o possibilita vivenciar a elaboração e processo de ensino e aprendizagem como um "fazer". Ou seja, o que queremos chamar atenção aqui é que o lugar da artesania perpassará não só as possíveis discussões que dizem respeito às problemáticas dos objetos estéticos bem como as ambiguidades que acarretam dimensões de habilidade e apego à forma bem feita. Antes, será a artesania promotora de um movimento necessário da experiência, quando capaz de tornar a docência elegível de um fazer construído de partes que compõem um todo. Este todo, entendemos, pode ser o gesto de ensinar.

\section{Apontamentos sobre artesania}

A acepção de arte, embora recente na história da humanidade, quando pensada em suas raízes, tem origens do latim e do grego. Sua compreensão leva à: artus (lat.), que estava ligado ao adjetivo "estreito" ou "bem ajustado", enquanto que o grego nos apresenta ararisko, referente à ação de harmonizar (CARCHIA; 


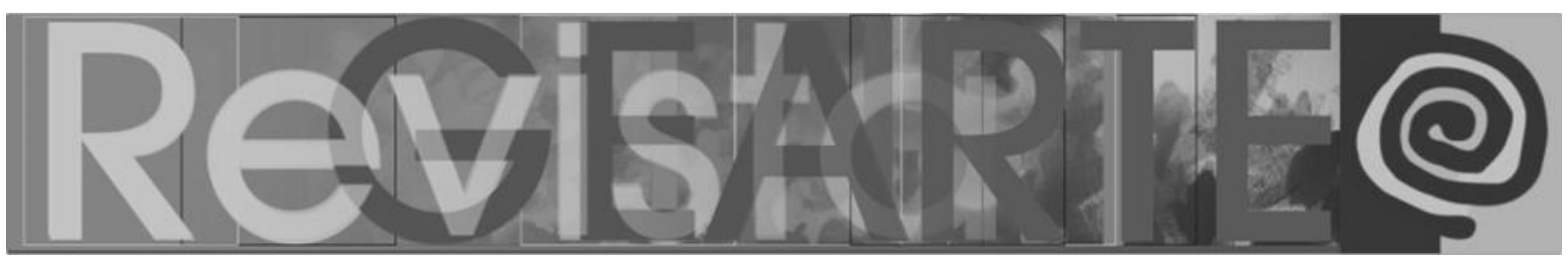

D'ANGELO, 1956). Entretanto e ainda consultando o Dicionário de Estética dirigido por Carchia e D'Angelo (1956, p. 33), compreende-se que "techné, ars e seus derivados referiam-se genericamente a qualquer atividade humana que implicasse um determinado saber fazer ordenado [...]". Nesse sentido, embora este texto não tenha a intenção de desenvolver a contenda entre arte e artesania, suas origens etimológicas nos encaminham ao lugar da produção como harmônica, compatível com uma aparência da realidade. Ou, como nos apresenta Platão, em $A$ república (1988): uma aparência da aparência da realidade.

Ainda não havia, numa perspectiva platônica, uma preocupação substancial com diferenças entre o que hoje se nomenclatura como arte ou artesanato, embora Platão considerasse dentro de um mesmo critério as artes de caçar, pintar ou construir. Seu pensamento, calcado na supremacia da filosofia como lugar de conhecimento avançado e mais próximo de um ideal da realidade, mantinha a manufatura em consonância com a produção de objetos. Quando sua preocupação era direcionada àquilo proveniente da produção poética, calcado de uma subjetividade, o caráter estético se tornava desviante do anseio moral por distanciar-se de qualquer ideal de verdade. Nesse sentido, discrepâncias entre a produção de um objeto estético e um poema emanam, uma vez que a palavra contornada por gestos estilísticos ecoava como uma falsa verdade, confundindo o pensamento e produzindo equívocos. Assim, aquilo a que se produzia com intenções de ordem poética ganhava uma designação de perigo.

Ainda no berço da tradição grega a respeito do nascimento do fazer artístico, considera-se o pensamento aristotélico como norteador do lugar da harmonia da forma enquanto definidora daquilo a que se poderia, naquele contexto, considerar belo (ARISTÓTELES, 1999). A respeito desses retornos da história da filosofia da arte, o que nos chama atenção - embora saibamos que a nomenclatura "arte" bem como "estética" ainda não existiam e eram reverberadas pela ideia de Belo -, é o fato de que há uma nuança separativa desde a primeira atenção dada àquilo que 


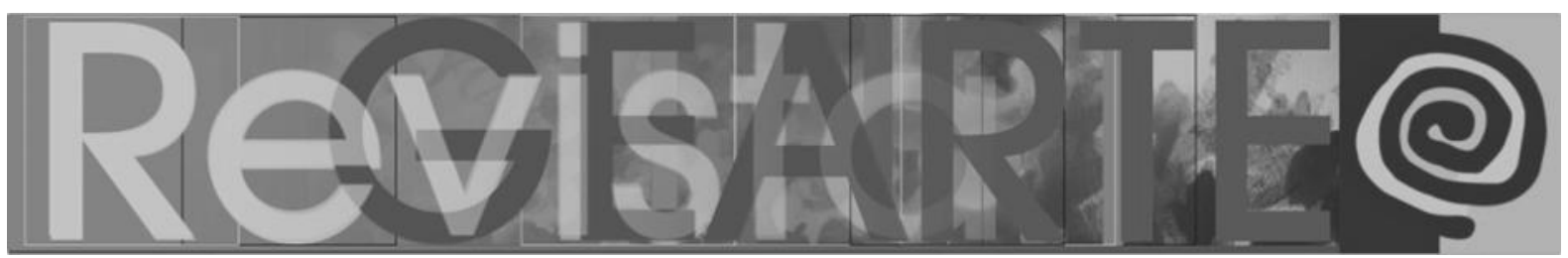

é produzido pela forma dos sentidos, àquilo a que se apega à imitação genuína da natureza e àquilo a que se atribuía uma funcionalidade.

Certos de que essa discussão milenar corrobora para uma história da arte, da filosofia da arte e da estética, ainda minadas de definições problemáticas, o que nos revela enquanto problematização a respeito da artesania é o lugar de perigo dado à forma poética e o lugar funcional dado à forma dos objetos cotidianos. Nesse ínterim, revela-se uma sutil desconsideração do manufaturado, quando colocado como produção de cunho técnico, funcional e não reflexivo. Dito isso e saltando drasticamente mais de dois mil anos de trajetória das problematizações filosóficas a respeito da forma do belo e, posteriormente, da arte, chegamos à artesania como gesto inerente ao sujeito e à sua história, uma vez que a produção dos sentidos se deve à relação desse sujeito com o mundo. De acordo com Souza e Fornari (2012), as implicações relacionadas com a produção de sentido em relação ao acontecimento formativo educacional transitam pelo reconhecimento de que a educação não é uma questão de método, "[...] mas de produção de sentido [pois] o conhecimento é sempre autoimplicativo, ou seja, é um modo de conhecer que, ao mesmo tempo em que amplia o conhecimento das coisas, amplia o saber sobre nós mesmos" (SOUZA; FORNARI, 2012, p. 110).

Assumindo, portanto, a artesania como produção de sentidos, assume-se também que essa ação revela elementos fecundos no que diz respeito à sua autoria, sua recepção e sua propagação. Assim, objetos produzidos no contexto da artesania são objetos calcados de valores estéticos, seja por sua forma e técnicas abordadas, seja por seu conteúdo histórico e cultural. Munidos dessa reflexão é que nos amparamos, novamente, em que Richter (2003) propõe enquanto vivência e experiência estética. Para a autora, as tendências do ensino da arte comungam para um movimento crítico contextualizado, atento ao fazer artístico e às experiências subjetivas provenientes desse gesto do fazer. 


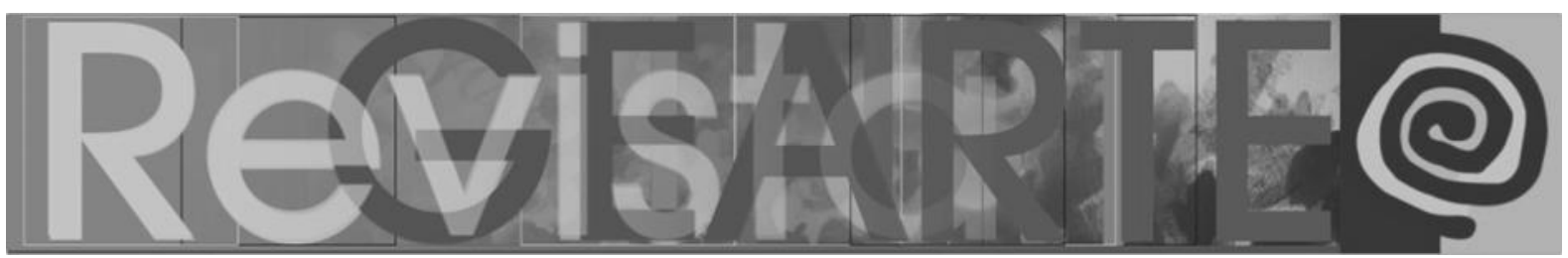

Atentamo-nos, portanto, a respeito da ambiguidade apontada por Sennett (2019), uma vez que a dialética entre mente e corpo é sintetizada pela atividade material, cujas habilidades e artesania são fortes componentes de aprendizagem pragmática do sujeito, transportando-o para uma esfera de importante desenvolvimento humano e seu conhecimento de si e do mundo. Entendemos que o fazer, nesse caso, enquanto lugar de manufatura, não é visto por Sennet (2019) como um gesto de mecanicidade, mas pode ser compreendido como potente movimento a respeito da experiência do sujeito. O confronto de Sennett com Hanna Arendt, presente no prólogo de $O$ Artífice (2019), revela não somente seu incômodo respeito da supremacia do homo faber em detrimento ao animal laborens, mas sua descrição dada ao lugar do fazer como tarefa absorta, com fim em si mesma. A separação contestada por Sennett leva-nos ao lugar da discussão da produção em série, artesanal, quando julgada enquanto mecânica e ausente de reflexão e intencionalidade estética. O filósofo nos conduz à introspecção do artesão, cujo comprometimento reflexivo é feito consigo mesmo, a respeito de suas escolhas e competência técnica. Mais do que isso, coloca-nos diante da artesania enquanto produção que se preocupa com a forma e que nenhuma forma é desprovida do conteúdo que a compõem bem como da sua construção enquanto objeto, funcional ou não. No mais, o lugar das coisas enquanto objetos se revela mantenedor de nuanças necessárias para compreensão de elementos denunciadores do contexto daquele que o produziu.

Uma vez assumindo o lugar de reflexão da manufatura, cujas preocupações do artesão ultrapassam o apego à forma harmônica por contemplarem vestígios de escolhas próprias do produtor, pode-se conversar a respeito da artesania como gesto de construção, cujos objetos promulgam movimentos que podem ser transportados para uma esfera didática. 


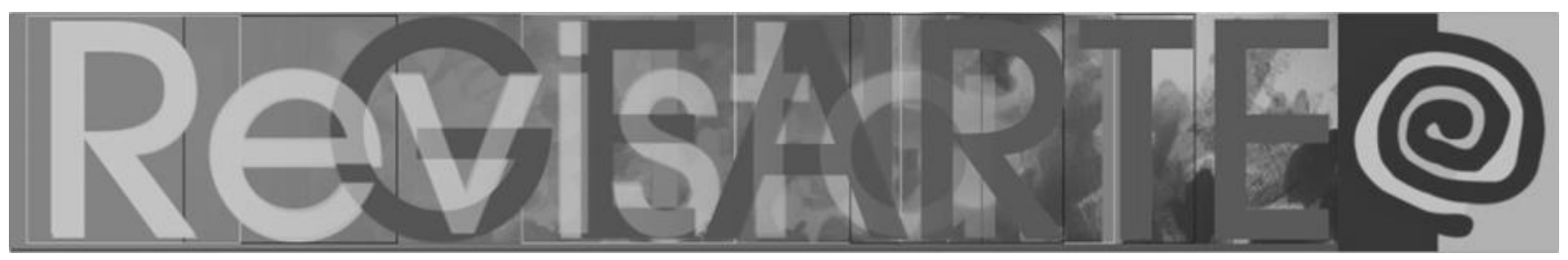

\section{Artesania como processo: implicações no/do cotidiano}

Como professores da licenciatura em Artes Visuais, emerge de nossas atuações cotidianas em sala de aula a necessidade de se reivindicar das experiências pedagógicas problematizações que nos permitam desenvolver reflexões a respeito da formação de futuros professores. Isto posto e vivenciando a oportunidade de se lidar com o estágio curricular, buscou-se estabelecer diálogos com elementos que o constituem, desde a elaboração do plano de curso às experiências dos discentes na escola. Ao elencarmos, aqui, dois níveis de estágio, observação e regência, reforçamos nossa preocupação em contextualizar as intenções desta etapa formativa da licenciatura em Artes Visuais, uma vez que a disciplina ambiciona despertar o olhar para o lugar da investigação em sala de aula: seja pela observação, cujo objetivo é pensar a respeito do funcionamento de uma instituição de ensino bem como a prática exercida por um professor regente; seja pela regência, em que o discente, com apoio do professor daquela turma, poderá experienciar situações de ensino e aprendizagem.

Ao considerarmos o exposto, compreendemos que as experiências que transitaram pelo estágio curricular em relação à disciplina de ESAV favorecem reflexões que são determinantes para o processo formativo dos discentes. Neste sentido, enquanto estratégia didática para compor a disciplina, foram propostos seminários que permitiram aos discentes compartilhar suas experiências bem como construir uma interlocução com o restante do grupo, cujo interesse foi compreender, por meio da experiência um do outro, como questões do ensino de Artes Visuais são complexas e precisam ser pensadas pelo professor enquanto preocupação com aquilo que diz respeito ao conteúdo, à didática e ao contexto e suas implicações. Entretanto, para fundamentar quaisquer desses apontamentos compartilhados, as escolhas didáticas da disciplina de estágio pressupunham discussões teóricas prévias que pudessem despertar um pensamento a respeito do lugar de atuação do docente bem como desenvolver estratégias metodológicas para sua realização. Por esta razão, ao apresentarem seus seminários, os discentes também entregaram um 


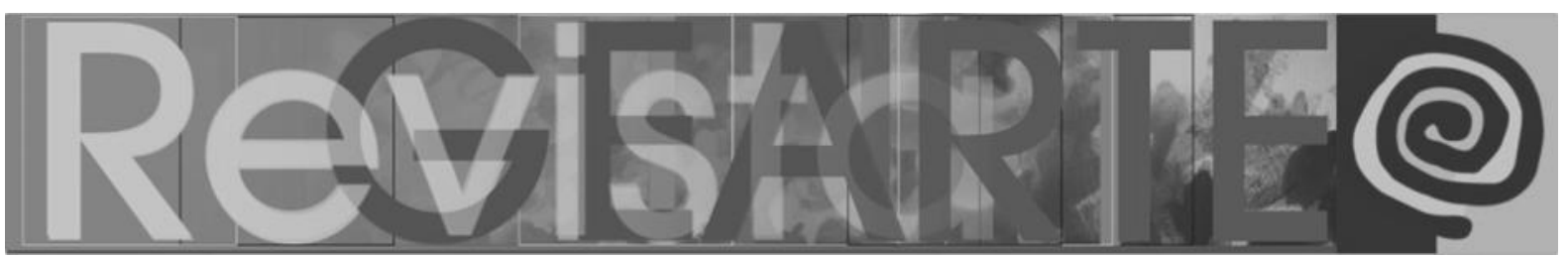

relatório crítico-reflexivo, em que conexões entre os textos lidos presencialmente e as experiências vivenciadas na escola pudessem ultrapassar o opinativo, ocupando, então, um lugar de questionamento e debate.

Nesse sentido, retomamos o pensamento de Richter (2003), quanto às questões experienciadas no estágio curricular em sua modalidade de observação e regência em Artes Visuais e salientamos o interesse pelo trabalho com a estética do cotidiano apontado pela autora. Essa dimensão da estética do cotidiano visa ampliar o domínio do conceito de arte, alargando o sentido mais limitado e excludente para uma dimensão que comporta outros olhares, de modo ampliado, para a experiência estética (RICHTER, 2003). Dessa forma, entendemos o estágio curricular como um caminho percorrido, pois dele resultam processos de percepção que possam minimizar os conceitos atrelados com a arte oriundos de uma perspectiva das Artes Visuais como "belas artes", "arte erudita", ou ainda, "arte maior", que se contrapõe a ideia de "artes menores" ou "artes populares". Reparamos, portanto, que, ao insistirmos no estágio em Artes Visuais como campo de pesquisa em conhecimento, estamos incentivando o despertar de competências críticas capazes de lidar com essas dicotomias por um viés mais fecundo, uma vez que o interesse não é sustentar discursos canônicos, mas conduzir o olhar às arestas deixadas por currículos que se encerram em apenas um caminho de conteúdo. É também por este esforço que se torna possível exercer a docência a partir das articulações daquilo que está posto diante do sujeito: as relações sensíveis com o mundo e o que o compõe.

Ao considerarmos tais relações sensíveis, questionamos como determinadas questões, condizentes com as dicotomias, lidam com um cenário contemporâneo, no qual temos a presença das visualidades cotidianas que interrogam permanentemente a escola e os docentes, tornando-se uma questão relevante para o contexto formativo em Artes Visuais. Por isso, pensamos que uma estética e, também, um cotidiano que grita pelos corredores da escola requer da comunidade escolar algum tipo de atenção que compreenda sua emergência. Para

CAIXETA, Ana Paula Aparecida; FERREIRA, Luiz Carlos Pinheiro. Artesania como processo: o estágio curricular em 498 Artes Visuais como espaço de observação e reflexão.

Revista GEARTE, Porto Alegre, v. 7, n. 3, p. 485-509, set./dez. 2020.

Disponível em: http://seer.ufrgs.br/gearte 


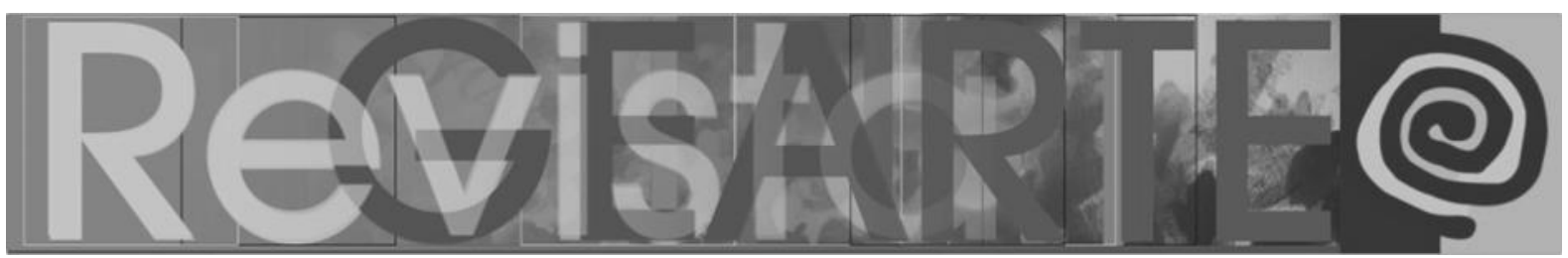

Certeau (1994), o cotidiano é permanentemente inventado para permitir o fluxo da vida, da criatividade e da invenção. Como ignorar o cotidiano dos nossos discentes que interagem fora do âmbito acadêmico com acontecimentos e imagens relacionadas com a televisão, a publicidade e outros meios de comunicação e informação que podem influenciar e motivar o processo educativo e o trabalho docente a partir de outros artefatos do cotidiano? De fato, não há como negligenciar tamanhas instâncias. Nesse ponto, o processo formativo institucional, do ponto de vista da educação básica à formação universitária, em especial no âmbito das Artes Visuais, precisa privilegiar e ressignificar pedagogicamente sua relação com outras visualidades presentes no cotidiano. Inclusive, considerar o modo como estão sendo estabelecidas em termos de propostas curriculares, ou mesmo, do estágio curricular realizado em determinadas instituições. De acordo com Tomaz Tadeu da Silva (1995, p. 193-194), "o currículo é também uma relação social, no sentido de que a produção de conhecimento envolvida no currículo se realiza através de uma relação entre pessoas". Então, se o currículo é algo que se realiza entre pessoas, nada mais prudente que considerar as experiências, os discursos e sentidos produzidos através das relações sociais praticadas em consenso no contexto pedagógico.

Ao considerar essas experiências, abre-se um caminho arenoso, porém, importante, no que diz respeito à docência e sua construção identitária enquanto escolhas didáticas e metodológicas. Quando Pimenta e Lima (2012) chamam atenção para o caráter de reflexão no que tange a função do estágio supervisionado, explanam criticamente sobre a imitação de modelos didáticos, quando feita a partir de apropriação de ações consideradas imutáveis e enrijecidas, sendo rotuladas como "artesanais". Ao exporem essa preocupação, as autoras voltam a reflexão para os problemas a respeito de uma prática modelar consagrada por instrumentos tradicionais. Para nós, cientes de que a experiência docente no período de formação depende de observação para se pensar uma construção prática de ensino, essa artesania associada a uma ação sem reflexão não condiz com os encaminhamentos dados por este texto. Porém, corroboramos com a preocupação das autoras com o

CAIXETA, Ana Paula Aparecida; FERREIRA, Luiz Carlos Pinheiro. Artesania como processo: o estágio curricular em 499 Artes Visuais como espaço de observação e reflexão.

Revista GEARTE, Porto Alegre, v. 7, n. 3, p. 485-509, set./dez. 2020.

Disponível em: http://seer.ufrgs.br/gearte 


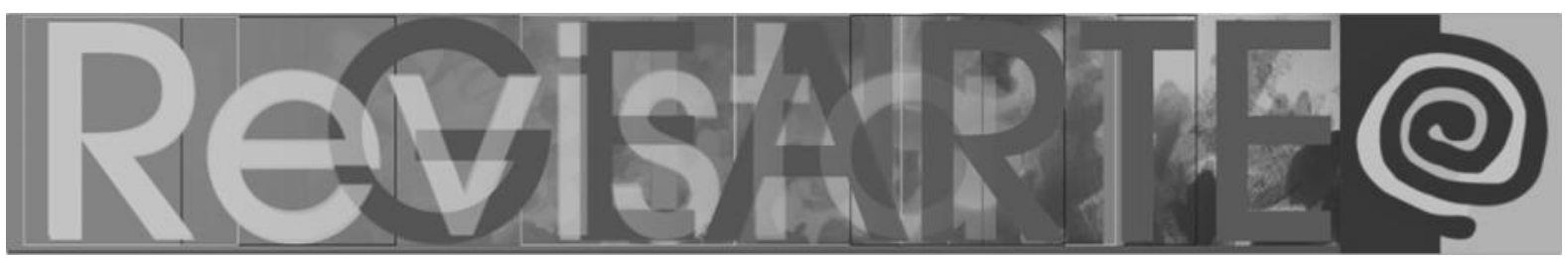

ensino enquanto ação que necessita constantemente de gestos reflexivos, seja pelo dinamismo proveniente da sala de aula, seja pelas intenções didáticas a respeito de um conteúdo. Mas estes gestos não são desprovidos de um fazer. Assim, a artesania seria, por que não, parte de um movimento de reflexão quando se propõe pensar didaticamente um componente curricular - no caso, Artes Visuais. Seja pelo próprio gesto de produção individual do sujeito professor na composição de material visual ou de qualquer outra linguagem, seja pelos elementos manufaturados produzidos pelo alunado quando propostas atividades de repetição, releitura e aprendizagem técnica. Neste caso, o que está em discussão passa a ser não a repetição de um modelo, mas a liberdade em se lidar com a técnica para a produção de instrumentos didáticos capazes de mediar um conteúdo a ser debatido em sala de aula.

Retomando o apontamento de Silva (1995), mediante a questão do currículo como algo que se realiza entre pessoas, nossa postura docente em sala de aula esteve subsidiada pelo diálogo, na tentativa de atrelar formação com experiência e sentido produzidos no estágio curricular. Ao considerar as experiências vivenciadas pelos discentes, quando trazidas por meio de apresentação oral e imagens das atividades realizadas na escola, estamos dando sentido tanto ao estágio curricular como para as interfaces com a artesania, pois identificamos aspectos que foram pontuais para pensar sobre o lugar do fazer no contexto do ensino em artes bem como as dicotomias conteudistas que ainda prevalecem no ambiente escolar. Para tanto, apresentamos dois apontamentos críticos realizados por discentes que fizeram seus estágios em escolas públicas, em níveis diferentes: o primeiro, observando três turmas do primeiro ano; a outra, observando turmas do Ensino Fundamental $1^{4}$.

\section{Observação e regência: questões reflexivas}

Em seu relatório, o discente comentou sobre o fato da professora utilizar material diverso, em que boa parte era proveniente de plataformas digitais bem 


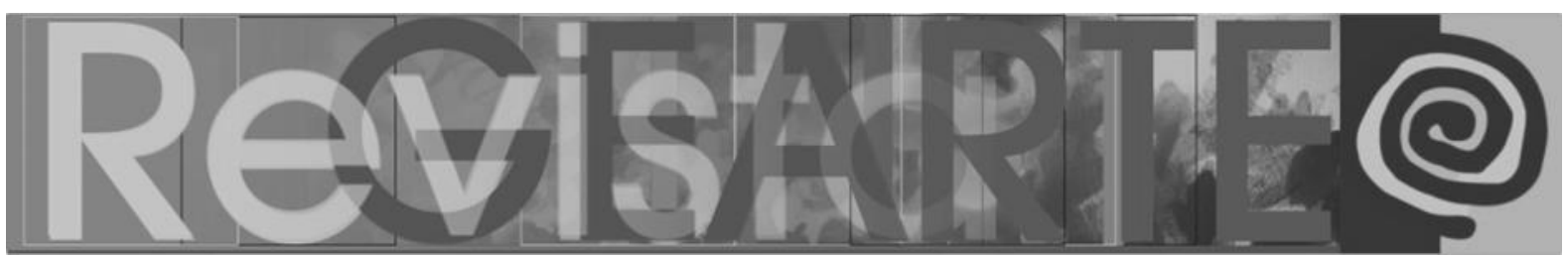

como os fornecidos pela Secretaria de Educação. O interessante do apontamento foi a atenção do aluno ao movimento da professora de subverter a escolha de materiais previamente ofertados aos professores, construindo uma rede de instrumentos didáticos a partir de vídeos de plataformas como o YouTube e sites que pudessem corroborar com o conteúdo teórico e prático, já então proposto. Nesse gesto dinâmico, a professora regente considerou artistas e elementos estéticos que contrariavam uma erudição e universalidade frequentemente anunciadas pelos livros de ensino de Artes Visuais, especialmente os voltados para um conteúdo de história da arte. A intencionalidade da professora para uma construção didática que pudesse contemplar o conteúdo a ser abordado questionava o lugar do modelo, uma vez que havia apenas um livro base indicado como recurso para o planejamento das aulas. Assim, o que nos interessa nesse relato são duas coisas: a primeira, de que o estagiário observou o movimento dinâmico da professora em subverter um conteúdo ou uma estratégia didática quando ela compreendeu serem seus instrumentos insuficientes para explanar um conteúdo e provocar um debate. A segunda foi o fato de que, desse gesto de reflexão a respeito da própria ação professoral, emerge uma preocupação com artistas e objetos que representam outras esferas históricas e culturais, nem sempre abordados pelo livro didático. Isso posto, entendemos que o processo de compreensão didática necessário ao desempenho da profissão é uma metáfora da artesania, uma vez que elenca e costura elementos variados, de origens múltiplas, em detrimento de uma intenção metodológica.

O relato apresentado pelo discente também desnuda um perfil docente que busca adaptar o interesse das turmas ao conteúdo da disciplina de Artes Visuais. Como uma artesania, ela elaborava semanalmente um roteiro que atendia as necessidades de cada turma. Observamos que essa postura privilegia um lugar do conhecimento atrelado, inicialmente às questões teóricas. Segundo Henry A. Giroux (1995), a teoria não é apenas a aprendizagem dos discursos de outras pessoas. Torna-se necessário teorizar a partir dos problemas e situações dos próprios estudantes, relacionando-os com seu contexto histórico e contemporâneo.

CAIXETA, Ana Paula Aparecida; FERREIRA, Luiz Carlos Pinheiro. Artesania como processo: o estágio curricular em 501 Artes Visuais como espaço de observação e reflexão.

Revista GEARTE, Porto Alegre, v. 7, n. 3, p. 485-509, set./dez. 2020.

Disponível em: http://seer.ufrgs.br/gearte 


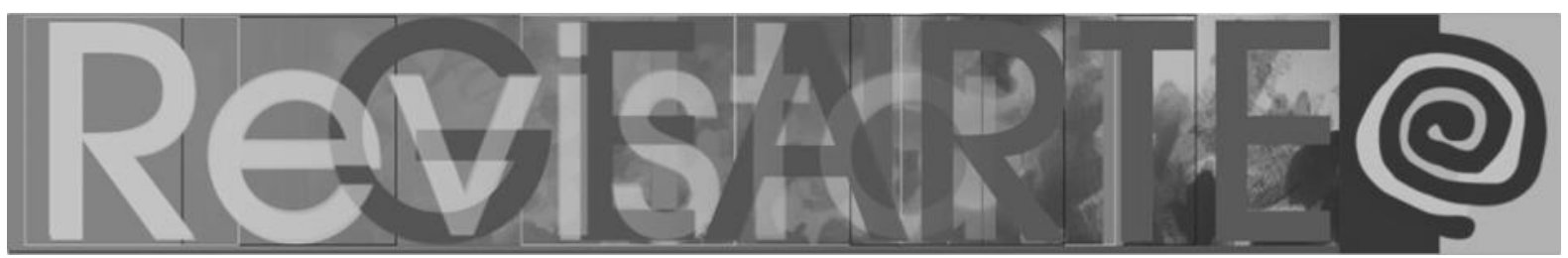

O apontamento de Giroux acentua a experiência formativa vivenciada pelo discente no estágio curricular, justamente pela iniciativa da professora que não se refreou perante as regras da Secretaria de Educação, promovendo um trabalho pedagógico que levava em conta o contexto e as demandas apresentadas pelas turmas para elaborar sua aula. Ainda, nessa perspectiva, Tourinho (2009b) pontua sobre os discursos dos sujeitos, os alunos, e suas experiências com as visualidades cotidianas, alertando-nos que eles não têm sido algo que, essencialmente, a escola privilegia, sobretudo, do ponto de vista pedagógico. Entretanto, entendemos que é dessa relação sujeito e visualidades cotidianas que podem surgir inferências, sentidos e significados como propostas curriculares que contemplem outros modos de conceber o ensino de Artes Visuais. Nesse caminho, entendemos que a prática pedagógica ofertada pela professora, a partir da observação do estagiário, preocupou-se com um repertório imagético diversificado, especialmente, em relação a produção de material que pudesse atender aos interesses das diferentes turmas. Sua prática assemelha-se a confecção artesanal de uma colcha de retalhos. Seleciona, organiza e costura artesanalmente diferentes repertórios e contextos mediante a pluralidade de imagens e conteúdos que são ofertadas cotidianamente.

Em outra experiência de estágio, agora em caráter de regência, foram trazidas algumas narrativas interessantes dos licenciandos a respeito da condução dessas aulas e das dificuldades enfrentadas na prática. Principalmente, revelouse, neste momento da formação, a difícil aplicação de um planejamento prévio para uma turma, até então, regida por outro profissional que não é o estagiário. Esse limbo identitário provoca uma relação complexa no que diz respeito ao processo de ministrar um conteúdo, conduzir à turma às propostas então elaboradas e promover um processo de ensino e aprendizagem junto a esse grupo designado. Mesmo diante das complexidades da ação de ensinar ou mediar um conteúdo, nota-se como o exercício da prática do estágio é importante, uma vez que permite uma experiência prática, mas, também, revela os bastidores de uma sala de aula, até então pensada pelo olhar de aluno.

CAIXETA, Ana Paula Aparecida; FERREIRA, Luiz Carlos Pinheiro. Artesania como processo: o estágio curricular em 502 Artes Visuais como espaço de observação e reflexão. Revista GEARTE, Porto Alegre, v. 7, n. 3, p. 485-509, set./dez. 2020.

Disponível em: http://seer.ufrgs.br/gearte 


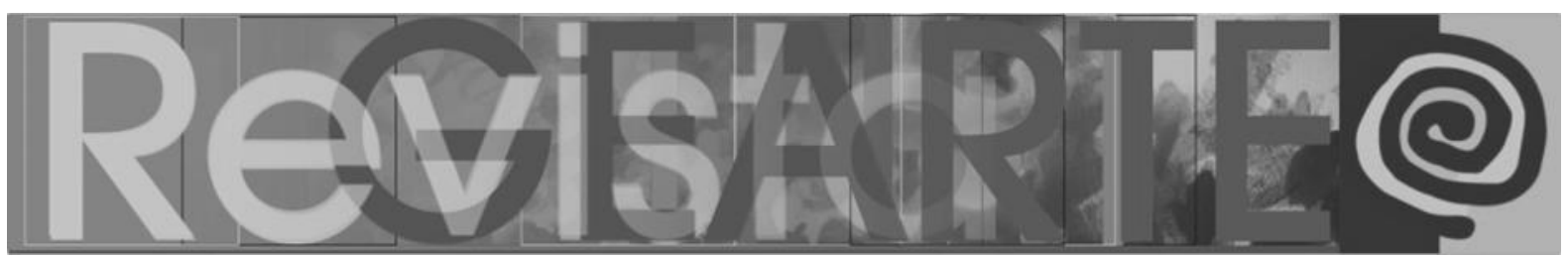

Dentre as revelações discutidas nas disciplinas de estágio, quando vivenciadas na escola, destaca-se uma em que a estagiária teve a oportunidade de observar e reger uma turma de crianças fora da habilitação formal da licenciatura em Artes Visuais (Ensino Fundamental II e Médio). A experiência em questão aconteceu em uma instituição específica de ensino de Arte (Visuais, Cênicas e Música) e Educação Física, mantida pela Secretaria de Educação da região, em que crianças em séries iniciais da rede pública são conduzidas para este local a fim de terem contato com conteúdos das referidas áreas, em caráter complementar. Na ocasião, a estagiária atentou-se quanto à forma de planejamento e escolha de conteúdo e material propostos pela professora regente a qual ela acompanhou. A aluna destacou como a preocupação com a manufatura foi significativa em relação ao lugar da reflexão, considerando que as etapas de aprendizagem do público dessa escola estavam em outro nível de desenvolvimento. Nesse sentido, revelou-se como a profissão do professor de Artes Visuais, naquele contexto, precisou se adaptar a um universo cuja prática artesanal possui caráter elementar, seja pelas estratégias didáticas da professora ao construir um material e propô-los aos alunos, seja pela necessidade de lidar com outras habilidades que, naquele momento, intencionavam uma preocupação muito mais motora que técnica, porém, com intenções de uma harmonia da forma, em se tratando de atividades de cópia e releitura. Ainda assim, as atividades ali observadas, embora trouxessem um movimento aparentemente mecânico, revelavam, em várias circunstâncias, as habilidades individuais das crianças ali envolvidas, resultando na compreensão a respeito das especificidades gestuais presentes desde os primeiros anos escolares. Também foi destaque, nesse relato, as conexões entre os projetos desenvolvidos e temas transversais, como higiene pessoal e meio ambiente. Isso caracteriza aspectos do fazer notoriamente direcionados às intenções de uma compreensão e aprendizado a respeito de elementos do cotidiano de qualquer criança. O elo imagético criado como elemento lúdico de aprendizagem intenciona, em experiências dessa natureza, uma construção de sentidos estabelecida pelos alunos. 


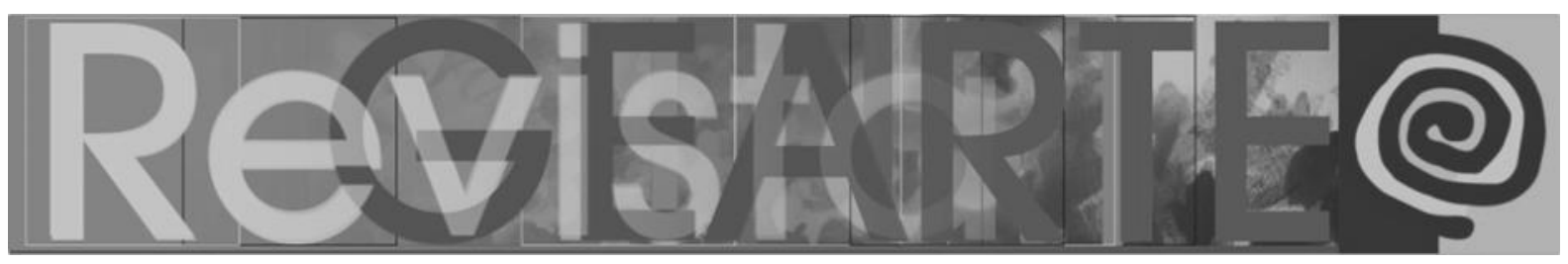

No momento de regência da estagiária, a primeira ação, após o processo de observação, foi compreender a estrutura curricular ali adotada bem como o planejamento anual da docente, cobrado aos professores ainda no início do ano. Posterior a esta investigação, foi possível à discente elaborar atividades que fizessem parte desse planejamento já existente, de modo que sua proposição não interferisse drasticamente ao que estava sendo trabalhado. Como os temas e materiais já eram estabelecidos, ou pela escola ou pela professora regente, a estagiária precisou se adaptar a estes direcionamentos, buscando formas de compreender cada escolha e como, em sua oportunidade de experiência, poderia contribuir ao se envolver com a turma. Desde consultas a regulamentos à compreensão do universo infantil a respeito de formas estéticas, leitura, imagem e representação, sua prática de estágio precisou ser adaptada para um universo de experiência, até então, novo. Na oportunidade, uma das reflexões feitas pela estagiária foi a respeito de como lidar com os conflitos das crianças quanto à habilidade em reproduzir a forma daquilo que conhecem ou imaginam. Em seu relatório crítico, ela aponta o recorrente gesto imitativo das crianças quanto ao trabalho manual, em que, ao confrontarem suas inabilidades, acabam por reproduzir o do colega ou solicitar auxílio manual da estagiária, com uma preocupação específica a respeito do modelo exibido em algum material. $\mathrm{O}$ que the chamou atenção, no caso, foi o fato de que a professora regente, acompanhando o processo, preocupava-se constantemente com o resultado final dos exercícios, cobrando uma uniformidade e harmonia nos trabalhos das crianças, para que pudessem ser expostos nos murais. Mesmo identificando essa abordagem, a estagiária explorou, por meio de atividades práticas de desenho, formas lúdicas de se trabalhar coletivamente, cuja preocupação não era o resultado, mas uma artesania que permeou a condução do processo. Essa proposta permitiu que as crianças pudessem reconhecer seus esforços manuais por partes para se compor um todo, uma vez que cada uma contribuía com uma parte dos desenhos propostos.

Ademais, dessa experiência, a discente estabeleceu conexões entre questões ligadas ao lugar da criatividade e formação estética ainda nas séries CAIXETA, Ana Paula Aparecida; FERREIRA, Luiz Carlos Pinheiro. Artesania como processo: o estágio curricular em 504 Artes Visuais como espaço de observação e reflexão. Revista GEARTE, Porto Alegre, v. 7, n. 3, p. 485-509, set./dez. 2020. 


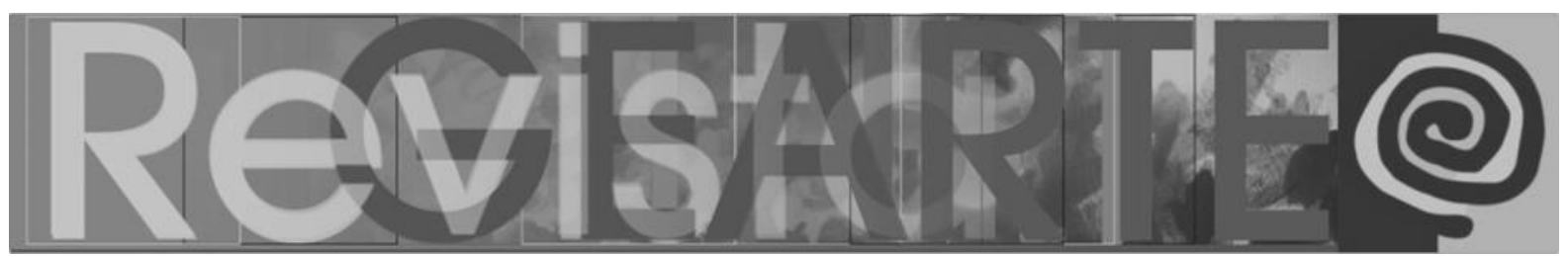

iniciais, revelando a necessidade de se construir uma prática docente capaz de reconhecer as sutilezas das formas da arte, quando trazidas para as especificidades do universo de uma idade/série, no âmbito formal de ensino. Independentemente de abordagens ainda atreladas ao fazer apenas como resultado de competência técnica, o que se construiu, neste caso, durante a experiência de estágio, foram problematizações que confrontaram a área de conhecimento e suas necessidades didáticas e metodológicas.

Os dois exemplos trazidos, embora explorados minimamente e recortados de outros múltiplos relatos, fornecem para este texto uma dimensão que intersecciona a experiência em sala de aula com questões que compõem currículo, cotidiano didática e metodologia. $\mathrm{O}$ ensinar, enquanto movimento de ação e reflexão, tal como propõem Pimenta e Lima (2012), é também uma proposta para se conduzir saberes e objetos que corroboram com um currículo. Mas um conteúdo proveniente de um componente curricular não deve ser anunciado fora de uma realidade condizente com a comunidade escolar, uma vez que a prática de ensino não implica uma mecanização de divulgação de informações, esvaziada de sentidos. O que nos interessa, portanto, é reforçar que a docência revela elementos camuflados de micro e macro histórias e contextos, considerando questões que fazem parte da composição de um universo cotidiano capaz de conduzir a reflexões importantes no que tangem, em especial, as Artes Visuais.

Quando Certeau (1994) retoma a perspectiva kantiana a respeito do fazer e da ciência, ele revela o gesto estético proveniente do pensar, em que teoria e práxis se interligam. As questões cotidianas que entremeiam a relação entre o sujeito e as coisas do mundo são o princípio de qualquer conhecimento, quando se pensa em sua experiência estética, tal como podemos conferir em Kant (2015). O que nos revela Certeau é como esse meio-termo, designado pelo comum e banal, é essencial a qualquer ideia de compreensão a respeito do sujeito e das coisas. Não se trata apenas de um tipo de elemento provocador de ajuizamento, sem conceito e interesse, se pensarmos nos julgamentos kantianos (KANT, 2010). 


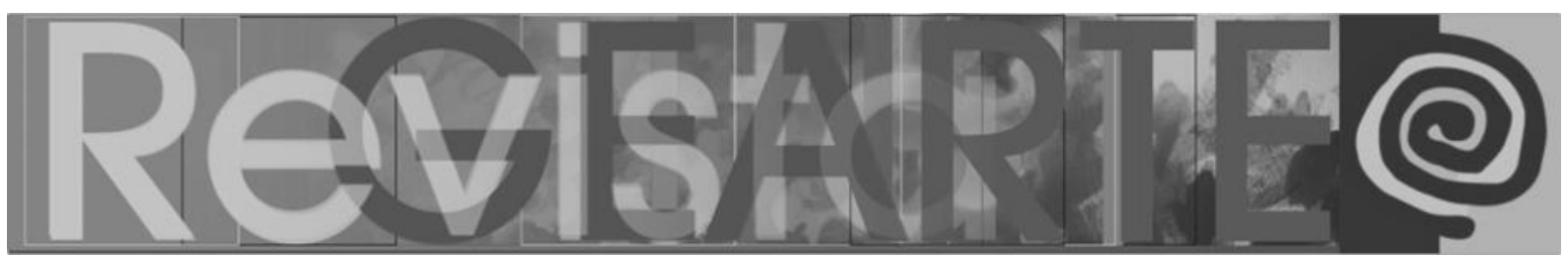

Trata-se, antes, de um lugar cuja preocupação maior é proveniente dessa relação de experiência inicial e pode ser reconhecido como a primeira instância a respeito de um entendimento das coisas.

Dito isso e ainda considerando o que nos provoca Certeau (1994), a experiência com aquilo que é da ordem do cotidiano é capaz de nos encaminhar a múltiplas possibilidades, nascidas ou não de modelos variados, mas que ganham força em uma bricolagem própria da ação de ensinar. Desse modo, a prática educativa no contexto das Artes Visuais torna-se um movimento capaz de sintetizar fundamentos teóricos em gestos pedagógicos, fomentados pelos sujeitos inclusos nesse processo, mas necessários de serem conduzidos senão por uma ação artesanal dos elementos inerentes a essa composição laboral.

O saber ensinar Artes Visuais é saber tecer elementos e o estágio curricular fornece esse primeiro contato com a tecitura, a medida em que expõe a prática docente como um trabalho que contempla construção e/ou condução material daquilo que corrobora com a reflexão estética. Os objetos passam, então, a dominar um lugar de intencionalidade, provenientes da razão, promovida pelo professor em sala de aula, cujas escolhas são intrínsecas ao lugar do conhecimento e, porque não dizer, da artesania.

\section{Considerações finais}

A formação inicial docente é um processo capaz de expor questões importantes, constitutivas da profissão bem como do sujeito que a escolhe. Quando Elizeu Clementino de Souza (2006) elenca o estágio como componente da formação do futuro professor, estabelece a narrativa de formação como ação metodológica desse entendimento. Mas essa narrativa não é só um instrumento necessário àquele que se dirige à escola para observar e elaborar um relatório crítico e reflexivo. Essa narrativa é elemento discursivo do docente universitário, condutor dos inúmeros diálogos que nascerão do contato com as experiências. Isso faz do lugar da sala de aula, tanto na formação superior quanto na educação 


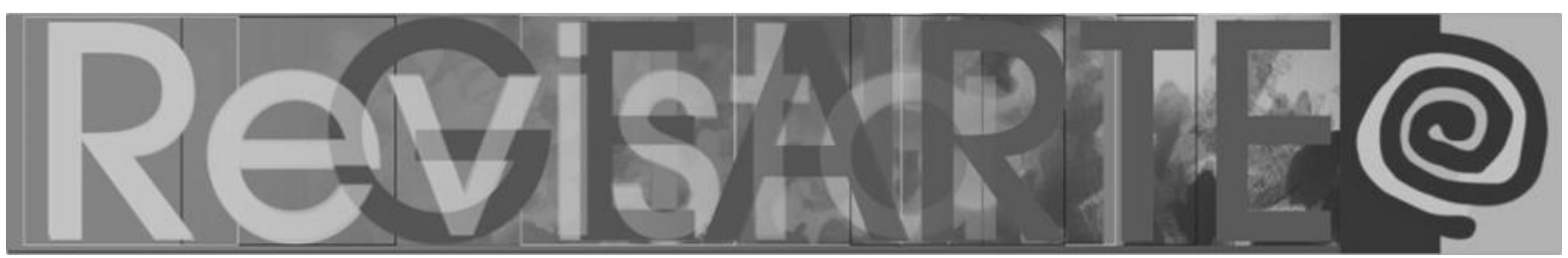

básica, um fecundo lugar de reflexão a respeito de todo e qualquer elemento que perpassa esse processo formativo e de experiência de vida. Rege, neste lugar, um movimento capaz de lidar com dispositivos próprios do universo pedagógico, quando a atenção se volta para as sutilezas do cotidiano em intersecção com conhecimentos estabelecidos. A formação docente constitui uma etapa de uma trajetória a ser construída senão pela sensibilidade dada às coisas que compõem os sujeitos e suas experiências. $E$ isso neutraliza o confronto entre a racionalidade técnica e o fazer baseado em vivências, uma vez que promove um movimento dinâmico, incapaz de se encerrar no conteúdo programático, mas potente de uma artesania que tece os saberes provenientes de questões de ordem estética.

\section{Notas}

1 Ofertamos, separadamente, a disciplina de Estágio Supervisionado em Artes Visuais observação e regência, respectivamente, no primeiro e segundo semestre letivo de 2018.

2 Não desdobraremos, neste texto, uma discussão acerca da Base Nacional Comum Curricular, embora sua menção seja necessária quanto ao conhecimento a respeito das habilidades e competências alinhadas ao currículo escolar. Disponível em: http://basenacionalcomum.mec.gov.br/. Acesso em: maio de 2019.

3 Estágio Supervisionado em Artes Visuais. Esta disciplina é dividida em dois níveis: observação e regência.

4 Esclarecemos que, embora a licenciatura em Artes Visuais, em caráter de ensino formal, não habilite para atuação em séries iniciais, uma vez que este papel é desempenhado pelo profissional de Pedagogia, considerou-se, neste caso, o critério geral para realização do estágio curricular: instituições que promovam ações educativas em artes, mediadas por profissionais licenciados para este fim. É o caso da escola em questão, escolhida pela estagiária por contemplar ensino em Artes Visuais para séries do primeiro seguimento.

\section{Referências}

ARISTÓTELES. Poética. Tradução de Baby Abrão. São Paulo: Nova Cultura, 1999.

BAKHTIN, Mikhail. Marxismo e filosofia da linguagem: problemas fundamentais do método sociológico na ciência da linguagem. Tradução de Michel Lahud e Yara Frateschi Vieira. São Paulo: Hucitec, 2004.

CARCHIA, Gianni; D’ÂNGELO, Paolo. Dicionário de estética. Tradução de Abílio Queirós e José Jacinto C. Serra. Lisboa: Edições 70, 2009.

CERTEAU, Michel de. A invenção do cotidiano: 1. Artes de fazer. Tradução de Ephraim Ferreira Alves. Petrópolis, Rio de Janeiro: Vozes, 1994.

DOLL JR., William E. Currículo: uma perspectiva pós-moderna. Tradução de Maria Adriana Verissimo Veronese. Porto Alegre: Artes Médicas, 1997. 


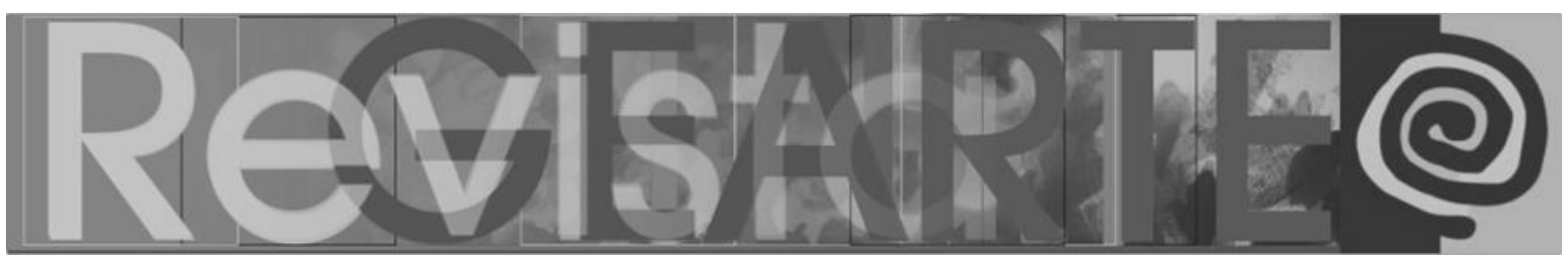

FERREIRA, Luiz Carlos Pinheiro. Mo(Vi)Mentos Autobiográficos: historiando fragmentos narrativos de experiências de vida docente e discente em Artes Visuais. Tese (Doutorado em Arte e Cultura Visual) - Faculdade de Artes Visuais, Universidade Federal de Goiás, Goiânia, Goiás, 2015.

GIROUX, Henry. Praticando estudos culturais nas faculdades de educação. In: SILVA, Tomaz Tadeu (Org.) Alienígenas na sala de aula: uma introdução aos estudos culturais em educação. Petrópolis, Rio de Janeiro: Vozes, 1995. p. 85-103.

KANT, Immanuel. Crítica da faculdade de juízo. Tradução de Valério Rohden e António Marques. Rio de Janeiro: Forense Universitária, 2010.

KANT, Immanuel. Crítica da razão pura. Tradução de Fernando Costa Mattos. Petrópolis, Rio de Janeiro: Vozes; Editora Universitária São Francisco, 2015.

PLATÃO. Diálogos III: a república. Tradução de Leonel Vallandro. Rio de Janeiro: Ediouro, 1988.

PIMENTA, Selma Garrido; LIMA, Maria Socorro L. L. Estágio e docência. São Paulo: Cortez, 2012.

PINAR, William E. O que é a teoria do currículo. Tradução de Ana Paula Barros e Sandra Pinto. Lisboa: Porto Editora, 2007.

RICHTER, Ivone M. Interculturalidade e estética do cotidiano no ensino das artes visuais. Campinas, São Paulo: Mercado das Letras, 2003.

SENNETT, Richard. O artífice. Tradução de Clóvis Marques. Rio de Janeiro: Editora Record, 2019. E-book (389 p.)

SILVA, Tomaz Tadeu da. Currículo e identidade social: territórios contestados. In: SILVA, Tomaz Tadeu da (Org.) Alienígenas na sala de aula: uma introdução aos estudos culturais em educação. Petrópolis: Vozes, 1995. p. 190-207.

SOUZA, Elizeu Clementino de. O conhecimento de si: estágio e narrativas de formação de professores. Rio de Janeiro: DP\&A; Salvador: UNEB, 2006.

SOUZA, Elizeu Clementino de; FORNARI, Liege Maria Sitja. Memória, (auto)biografia e formação. In: VEIGA, Passos Alencastro; D’ÁVILA, Cristina Maria (Orgs.) Profissão docente: novos sentidos, novas perspectivas. Campinas, São Paulo: Papirus, 2012. p. 109-134.

TOURINHO, Irene. Comitê de Educação em Artes Visuais: uma análise das questões de pesquisa da Anpap 2008. In: ENCONTRO DA ASSOCIAÇÃO NACIONAL DE PESQUISADORES EM ARTES PLÁSTICAS: TRANSVERSALIDADES NAS ARTES VISUAIS, 18., 2009, Salvador. Anais..., Salvador: EDUFBA, 2009b. p. 3347-3361. Disponível em: <www.anpap.org.br>. Acesso em: 20 nov. 2010.

TOURINHO, Irene. Educação estética, imagens e discursos: cruzamentos nos caminhos da prática escolar In: MARTINS, Raimundo; TOURINHO, Irene (Orgs.) Educação da cultura visual: narrativas de ensino e pesquisa. Santa Maria: Editora da UFSM, 2009b. p. 141-156.

TOURINHO, Irene. Perguntas que conversam sobre educação visual e currículo. In: OLIVEIRA, Marilda Oliveira de; HERNANDEZ, Fernando (Orgs.). A formação do professor e o ensino das artes visuais. Santa Maria: Editora da UFMS, 2015. p. 75-88.

\section{Ana Paula Aparecida Caixeta}

Doutora e mestre em Literatura pela Universidade de Brasília (UnB). Graduada em Artes Plásticas (UnB) e Letras (ICSH) com especialização em Língua Portuguesa. É professora adjunta do Departamento de Artes Visuais da Universidade de Brasília e professora do Programa de PósGraduação em Literatura (PósLit/UnB). Tem experiência de ensino na educação básica estadual de Goiás e no Instituto Federal de Goiás. É pesquisadora e líder do grupo Epistemologia do Romance, buscando, atualmente, construir diálogos entre Literatura e Artes Visuais por meio da 


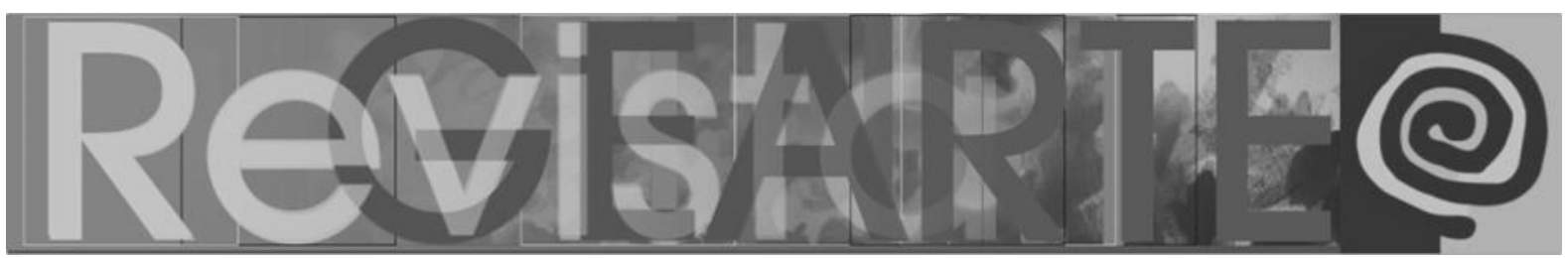

teoria da Epistemologia do Romance. Desenvolve pesquisas sobre Estética, Efeito estético e Ensino da Estética.

ORCID: https://orcid.org/0000-0002-4923-8744

E-mail: caixetaanapaula@yahoo.com.br

Currículo: http://lattes.cnpq.br/6443941763838130

\section{Luiz Carlos Pinheiro Ferreira}

Doutor em Arte e Cultura Visual pelo Programa de Pós-Graduação em Arte e Cultura Visual da Universidade Federal de Goiás, área de concentração em Arte, Cultura e Visualidades na Linha de Pesquisa: Culturas da Imagem e Processos de Mediação com a tese: MO(VI)MENTOS AUTOBIOGRÁFICOS: historiando fragmentos narrativos de experiências de vida docente e discente em artes visuais. Mestre em Educação pelo Programa de Pós-Graduação em Educação da Universidade Federal Fluminense no Campo de Confluência: Linguagem, Subjetividade e Cultura (2008), com enfoque no estudo do conceito de subjetividade e linguagem a partir da imagem fotográfica publicitária. Tem graduação com Licenciatura Plena em Educação Artística pela Universidade do Estado do Rio de Janeiro (1996). Lecionou Artes Visuais e História da Arte nas redes municipal e estadual do Rio de Janeiro no período de 1998 a 2009. É professor adjunto na Universidade de Brasília, lotado no Instituto de Artes, Departamento de Artes Visuais e orientador de Mestrado credenciado no Programa de Pós-Graduação em Artes Visuais - PPGAV/UNB, com o Projeto de Pesquisa: Experiências de vida, formação e autoformação: dialogicidade entre pesquisa narrativa, autobiografia e artes visuais.

ORCID: https://orcid.org/0000-0002-8823-6346

E-mail: luizcpferreira@gmail.com

Currículo: http://lattes.cnpq.br/0041084356285028

Recebido em 31 de maio de 2020 Aceito em 19 de agosto de 2020 